\title{
Table of Contents VOLUME I
}

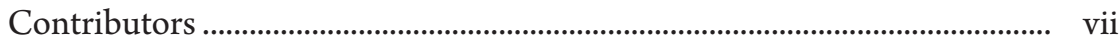

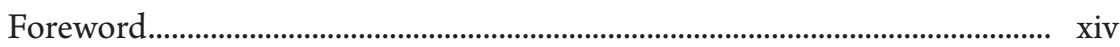

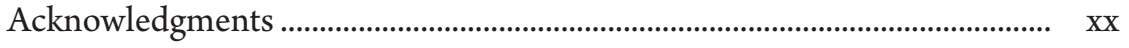

\section{Introduction}

The Problematics of Jewish Collective Action: Community and Conflict and Change

Eric Levine

\section{Mobilizations, Contentious Politics, and} Collective Action

Opportunity, Honor, and Action in the Warsaw Ghetto Uprising of 1943

Rachel L. Einwohner.

Musar and Modernity: The Case of Novaredok

David E. Fishman. 
Exhibiting Dreyfus in America: The Jewish Museum of New York and the Soviet Jewry Movement

Maya Balakirsky Katz.

Ritualized Protest and Redemptive Politics: Cultural Consequences of the American Mobilization to Free Soviet Jewry

Shaul Kelner

"A Strike in Heaven”: The Montreal Rabbis' Walkout of 1935 and its

Significance

Ira Robinson

Between Militarism and Pacifism: Conscientious Objection and Draft

Resistance in Israel

Yulia Zemlinskaya..

\section{Social Trends, Communal and Institutional Change}

Israeli and American Organizational Responses to Wife Abuse Among the Orthodox

Roberta Rosenberg Farber

American Jewish Hospitals and "The Jewish Problem” in American Medical Education

Edward C. Halperin

Emancipation, Modernity, and Jewish Identity in America

Mervin F. Verbit..

Index 